\title{
MRSA and enterobacteria of one health concern in wild animals undergoing
}

\section{rehabilitation}

MRSA e enterobacterias importantes para saúde única em animais sillvestres em reabilitação

MRSA y enterobacterias importantes para la salud única en animales salvajes en rehabilitación

Débora Rodrigues Silveira

ORCID: https://orcid.org/0000-0002-7245-279X Universidade Federal de Pelotas, Brazil E-mail: debora.rsilveira@hotmail.com

Thamíris Pereira de Moraes

ORCID: https://orcid.org/0000-0002-1513-930X Universidade Federal de Pelotas, Brazil E-mail: https://orcid.org/0000-0002-1513-930X

Kauana Kaefer

ORCID: https://orcid.org/0000-0003-1968-3684 Universidade Federal de Pelotas, Brazil

E-mail: kauanakaefer@gmail.com

Luiz Gustavo Bach

ORCID: https://orcid.org/0000-0002-0913-8538 Universidade Federal de Pelotas, Brazil

E-mail: lugubach@hotmail.com

Amanda de Oliveira Barbosa

ORCID: https://orcid.org/0000-0003-2888-7822 Universidade Federal de Pelotas, Brazil E-mail: barbosa.oamanda@gmail.com

Valéria Defavari Moretti

ORCID: https://orcid.org/0000-0002-6160-3505 Universidade Federal de Pelotas, Brazil

E-mail: vamoretti93@gmail.com

Paulo Quadros de Menezes

ORCID: https://orcid.org/0000-0002-9898-9851

Universidade Federal de Pelotas, Brazil

E-mail: pauloquadros.vet@gmail.com

Uila Silveira de Medeiros

ORCID: https://orcid.org/0000-0002-6588-0200 Universidade Federal de Pelotas, Brazil

E-mail: uilamedeiros@gmail.com

Thassiane Targino da Silva

ORCID: https://orcid.org/0000-0001-9626-311X Universidade Federal de Pelotas, Brazil

E-mail thassiane.vet@gmail.com

Paulo Mota Bandarra

ORCID: https://orcid.org/0000-0001-5441-205X

Universidade Federal de Pelotas, Brazil

E-mail: bandarra.ufpel@gmail.com

Luiz Fernando Minello

ORCID: https://orcid.org/0000-0002-8777-1355 Universidade Federal de Pelotas, Brazil E-mail: minellolf@hotmail.com

Cláudio Dias Timm

ORCID: https://orcid.org/0000-0003-3920-9066 Universidade Federal de Pelotas, Brazil E-mail: timm@ufpel.edu.br

\begin{abstract}
The presence of contaminated animals in wildlife rehabilitation centers poses a threat for both animals and humans that come into contact with them or the contaminated environment. The aim of this study was to assess the presence of Staphylococcus aureus, including methicillin-resistant S. aureus (MRSA), as well as studying the biofilm formation capacity of these isolates, Yersinia enterocolitica, Salmonella enterica and Campylobacter spp. in wild animals from a rehabilitation center. During a two-year period, feces were collected from animals that were admitted to a wildlife
\end{abstract}


rehabilitation center ( $\mathrm{n}=324$ samples). The pathogens were isolated from $51(15.7 \%)$ animals of different species of mammals, birds and reptiles. Forty isolates (12.3\%) were identified as S. aureus, of these, $32(9.9 \%)$ were identified as MRSA and $72.5 \%$ were able to form biofilm. Y. enterocolitica was found in five mammals (5.1\%), three reptiles $(21.43 \%)$ and two birds (0.94\%). Salmonella and Campylobacter were isolated from one bird each $(0.67 \%$ and $0.67 \%$, respectively). A wide diversity of animal species in rehabilitation centers, including birds, mammals and reptiles, can carry MRSA and enterobacteria of one health concern and eliminate in the feces. The presence of these pathogens in the gastrointestinal tract of wild animals admitted to a wildlife rehabilitation center shows the importance of microbiological monitoring of animals at the time of their admission and reinforces the need for specific hygienicsanitary care.

Keywords: Biofilm; Birds; Campylobacter; Mammals; Reptiles; Salmonella; Staphylococcus aureus; Yersinia enterocolitica.

\section{Resumo}

A presença de animais contaminados em centros de reabilitação de animais silvestres representa uma ameaça para os animais e humanos que entram em contato com eles ou com o ambiente contaminado. O objetivo deste estudo foi avaliar a presença de Staphylococcus aureus, incluindo S. aureus resistente à meticilina (MRSA), bem como estudar a capacidade de formação de biofilme destes isolados, Yersinia enterocolitica, Salmonella enterica e Campylobacter spp. em animais silvestres recebidos em um centro de reabilitação. Durante o período de dois anos, foram coletadas fezes de animais recebidos em centro de reabilitação de fauna silvestre $(n=324$ amostras). Os patógenos foram isolados de $51(15,7 \%)$ animais de diferentes espécies de mamíferos, aves e répteis. Quarenta isolados (12,3\%) foram identificados como $S$. aureus, destes, 32 (9,9\%) foram identificados como MRSA e 72,5\% foram capazes de formar biofilme. $Y$. enterocolitica foi encontrada em cinco mamíferos $(5,1 \%)$, três répteis $(21,43 \%)$ e duas aves $(0,94 \%)$. Salmonella e Campylobacter foram isoladas de uma ave cada $(0,67 \%$ e $0,67 \%$, respectivamente). Uma grande diversidade de espécies animais em centros de reabilitação, incluindo aves, mamíferos e répteis, podem carrear MRSA e enterobactérias tornando-se um problema de saúde por eliminá-las nas fezes. A presença desses patógenos no trato gastrointestinal de animais silvestres internados em centro de reabilitação de fauna silvestre demonstra a importância do monitoramento microbiológico dos animais no momento de sua internação e reforça a necessidade de cuidados higiênico-sanitários específicos.

Palavras-chave: Biofilme; Aves; Campylobacter; Mamíferos; Répteis; Salmonella; Staphylococcus aureus; Yersinia enterocolitica.

\section{Resumen}

La presencia de animales contaminados en los centros de rehabilitación de animales salvajes representa una amenaza para los animales y los seres humanos que entran en contacto con ellos o con el medio ambiente contaminado. El objetivo de este estudio fue evaluar la presencia de Staphylococcus aureus, incluyendo S. aureus resistente a meticilina (MRSA), así como estudiar la capacidad de formación de biopeliculas de estos, Yersinia enterocolitica, Salmonella enterica y Campylobacter spp. en animales salvajes recibidos en un centro de rehabilitación. Durante el período de dos años, se colectaron heces de animales recibidos en un centro de rehabilitación de vida silvestre $(\mathrm{n}=$ 324 muestras). Se aislaron patógenos de $51(15,7 \%)$ animales de diferentes especies de mamíferos, aves y reptiles. Cuarenta aislamientos (12,3\%) fueron identificados como S. aureus, de estos, $32(9,9 \%)$ fueron identificados como MRSA y el 72,5\% pudieron formar biopelículas. $Y$. enterocolitica se encontró en cinco mamíferos $(5,1 \%)$, tres reptiles $(21,43 \%)$ y dos aves (0,94\%). Se aislaron Salmonella y Campylobacter de un ave cada $(0,67 \%$ y $0,67 \%$, respectivamente). Una gran diversidad de especies animales en centros de rehabilitación, incluyendo aves, mamíferos y reptiles, pueden ser portadores de MRSA y enterobacterias, convirtiéndose en un problema de salud al eliminarlas en las heces. La presencia de estos patógenos en el tracto gastrointestinal de los animales salvajes ingresados en un centro de rehabilitación de vida silvestre demuestra la importancia del monitoreo microbiológico de los animales al momento de su ingreso y refuerza la necesidad de cuidados higiénico-sanitarios específicos.

Palabras clave: Biopelícula; Aves; Campylobacter; Mamíferos; Reptiles; Salmonella; Staphylococcus aureus; Yersinia enterocolitica.

\section{Introduction}

The abundance of animals admitted to wildlife rehabilitation centers offers a unique opportunity for research activities addressing pathogenic microorganisms (Yabsley, 2019). The presence of animals carrying pathogenic microorganisms in a wildlife rehabilitation center represents a threat for both animals and humans that come into contact with them or the contaminated environment. However, little has been studied about the species of wild animals capable of acting as pathogen carriers responsible for bacterial diseases (Tompkins et al., 2015), which makes difficult the adoption of preventive measures 
in the facilities that admit these animals.

Staphylococcus aureus, especially methicillin-resistant S. aureus (MRSA), which is one of the main agents of nosocomial life-threatening infections, due to its difficult treatment (Silva et al., 2020), Yersinia enterocolitica, Salmonella enterica and Campylobacter spp. are pathogens of great one health concern and have already been isolated from the gastrointestinal tract of wild animals (Centers for Desease Control and Prevention - CDC, 2017; Chambers, 2001; Porrero et al., 2013; Silveira et al., 2018; Gomes et al., 2011; Dias, 2015). These reports, however, address a very limited number of species that can be carriers of these microorganisms within a vast universe of species that must be studied.

Information concerning the species of animals that are associated with the transmission of pathogens, as well as the frequency of carriers, is necessary for the adoption of effective measures to control the spread of these microorganisms in wildlife rehabilitation centers. The understanding of specific characteristics of the bacteria carried by animals is also important for design of hygienic-sanitary protocols that should be adopted.

Biofilm is a community of sessile microorganisms characterized by cells that adhere to a surface, embedded in an extracellular matrix formed by exopolysaccharides. The ability to form biofilm is a trait that directly affects the elimination of the microorganisms from different surfaces (Donlan and Costerton, 2002). The presence of pathogens capable of forming biofilm in wildlife rehabilitation centers can make their elimination from facilities, equipment and utensils more difficult.

The objective of this study was to identify the occurrence of S. aureus, Y. enterocolitica, Salmonella and Campylobacter in the gastrointestinal tract of wild animals undergoing rehabilitation and to test the methicillin-resistance and the biofilm formation capacity of the isolated S. aureus.

\section{Methodology}

\section{Sample collection}

During two-year the Núcleo de Reabilitação da Fauna Silvestre e Centro de Triagem de Animais Silvestres Universidade Federal de Pelotas (NURFS/CETAS-UFPel) was monitored weekly. A qualitative (Pereira et al., 2018) censustype study was conducted considering the animals received and lodge in the nucleus the population, with the exception of those submitted to the liberation soon after clinical evaluation and those that died until the collection date, always performed on Mondays. The collection of feces from wild animals was carried out directly from the rectum or cloaca, using sterile swabs moistened in $0.85 \%$ saline solution. The swabs were placed in Cary Blair transport medium (Himedia, Mumbai, India) and immediately sent to the laboratory in isothermal boxes with ice.

The animals were taxonomically identified according to the Annotated Checklist of Brazilian Mammals (Paglia et al., 2012), the Annotated checklist of the birds of Brazil by the Brazilian Ornithological Records Committee (Piacentini et al., 2015) and Brazilian Reptiles: List of Species (Costa \& Bérnils, 2015).

\section{Isolates obtention}

The determination of the presence of coagulase-positive Staphylococcus was performed according to Timm et al. (2016), with modifications. Swabs with fecal samples were directly spread on Baird-Parker agar surface (Himedia, Mumbai, India) and incubated at $37^{\circ} \mathrm{C}$ for $48 \mathrm{~h}$.

To assess Y. enterocolitica, streaking was performed on MacConkey agar (MC, Himedia). After incubation at $37^{\circ} \mathrm{C}$ for $48 \mathrm{~h}$, three lactose negative colonies were spread on BHI and incubated at $37^{\circ} \mathrm{C}$ for $24 \mathrm{~h}$. Afterwards, motility tests were performed (Weagant \& Feng, 2017). 
To detect Salmonella spp., swabs were placed in $10 \mathrm{~mL}$ of Buffered Peptone Water (APT, Acumedia) for preenrichment and other procedures, as recommended by the U.S. Food and Drug Administration - FDA (Andrews et al., 2014). BHI cultures of the isolates were mixed with $20 \%$ glycerol to maintain stock at $-18^{\circ} \mathrm{C}$. When necessary, the isolates were recovered in $\mathrm{BHI}$ at $37^{\circ} \mathrm{C}$ for $24 \mathrm{~h}$.

For the isolation of Campylobacter spp., swabs with fecal samples were directly spread on the surface of Columbia Blood Agar Base (Acumedia, Lansing, United States), enriched with 0.4\% (m/v) of activated carbon, 5\% (m/v) of FBP oxygen reducing solution, $1 \%(\mathrm{~m} / \mathrm{v})$ of Campylobacter I supplement (Himedia, Mumbai, India) and a mixture of antibiotics. The plates were incubated at $42{ }^{\circ} \mathrm{C}$ for $48 \mathrm{~h}$ in a microaerophilic atmosphere $(85 \% \mathrm{~N} 2,10 \% \mathrm{CO} 2,5 \% \mathrm{O} 2)$. The typical colonies, which were spread and glistening, were submitted to morphotintorial classification by Gram stain.

\section{Molecular identification}

The DNA of the isolates was extracted according to Sambrook and Russel (2001) and stored at $-18{ }^{\circ} \mathrm{C}$. For complete cell lysis of the coagulase-positive Sthaphylococcus isolates, $100 \mu \mathrm{L}$ of lysostaffin solution $(100 \mu \mathrm{g} / \mathrm{mL}$ of lysostaffin in 20 $\mathrm{mM}$ acetate buffer) was added to the pellet obtained from the centrifugation of the culture in $\mathrm{BHI}$ and incubated at $37{ }^{\circ} \mathrm{C}$ for 1h.

To identify S. aureus, multiplex-PCR was performed, according to the protocol developed by Sasaki et al. (2010), which also allows the identification of S. intermedius and S. hycus, by probing the nuc gene. PCR was performed to identify Y. enterocolitica, according to Wannet et al. (2001), with modifications, since the ail gene was not assessed, and the corresponding primers were replaced by water. The PCR products stained with Diamond Nucleic Acid Dye (Promega, Madison, United States of America) were visualized in 1\% agarose gel electrophoresis (Panreac Química SA, Barcelona, Spain).

\section{Identification of MRSA}

To determine methicillin resistance in the S. aureus isolates, $30 \mu \mathrm{g}$ of Cefoxitin (CFO) was used in the disk-diffusion test (Skov et al., 2003; Felten et al., 2002). The cultures in BHI were standardized in a spectrophotometer at $600 \mathrm{~nm}$ for 0.5 optical density (OD) corresponding to the concentration $108 \mathrm{CFU} / \mathrm{mL}$. With the aid of sterile swabs the cultures were evenly distributed on the surface of a Mueller Hinton agar (Kasvi, Roseti Degli Abruzzi, Italy). The disc impregnated with Cefoxitin was disposed on the surface of the inoculated medium. The plates were incubated at $37{ }^{\circ} \mathrm{C}$ for $24 \mathrm{~h}$. Plate reading was performed by measuring and classifying the inhibitory halos according to the National Committee for Clinical Laboratory Standards - NCCLS (2008), which establishes as resistant the isolates with inhibitory halos with diameters of less than or equal to $21 \mathrm{~mm}$, and as sensitive the isolates with inhibitory halos equal to or greater than $22 \mathrm{~mm}$ of diameter.

\section{Verification of biofilm formation}

Biofilm production capacity of the S. aureus isolates was assessed by cultivation of colonies on Congo Red Agar (CRA), using 0.8g of Congo Red dye (Exodus Cientifica, Sumaré, Brazil) diluted into 1 liter of agar Brain Heart Infusion (Himedia, Mumbai, India) and 50g of sucrose (Freeman et al., 1989). The inoculants were streaked on the agar and incubated at $37^{\circ} \mathrm{C}$ for $48 \mathrm{~h}$ and then at $25^{\circ} \mathrm{C}$ for $48 \mathrm{~h}$ (Mariana et al., 2009). Cultures that exhibited rough and black colonies were considered biofilm producers. A strain of $S$. aureus previously identified as a biofilm producer by Friedriczewski et al. (2018) was used as a positive control and the ATCC 14458 strain was used as a negative control, since it does not form biofilms.

The experimental procedures were approved by the Ethics Committee on Animal Experimentation (CEEA) of the 
Veterinary Faculty of the Universidade Federal de Pelotas under the registration code CEEA 2640-2014.

\section{Results}

Out of the 324 wild animals sampled, $212(66 \%)$ were birds, $98(30 \%)$ were mammals and $14(4 \%)$ were reptiles. S. aureus, Campylobacter sp., Y. enterocolitica and S. enterica were isolated from 51 (15.7\%) animal species included in these three classes. Forty isolates were identified as $S$. aureus, which means that among the 324 animals collected, $12.3 \%$ borne this bacterium. Of these, $32(80 \%)$ were identified as MRSA, which corresponds to $9.9 \%(32 / 324)$. A total of $72.5 \%$ of the isolates were able to form biofilm (Table 1).

Table 1 - Relation of animals that hosted Staphylococcus aureus, the sensitivity of the strain to cefoxitin (CFO), and biofilm formation capacity.

\begin{tabular}{|c|c|c|c|c|}
\hline \multirow[t]{2}{*}{ Class } & \multicolumn{2}{|l|}{ Specie } & \multirow[t]{2}{*}{ Sensitivity to } & \multirow[t]{2}{*}{ Biofilm formation } \\
\hline & Common name & Scientific name & & \\
\hline \multirow[t]{20}{*}{ Aves } & Brown-chested martin (1) & Progne tapera & $\mathrm{R}^{*}$ & $\mathrm{~N}^{* * *}$ \\
\hline & Brown-chested martin (2) & Progne tapera & $\mathrm{R}$ & $\mathrm{F}^{* * * *}$ \\
\hline & Great kiskadee (1) & Pitangus sulphuratus & $\mathrm{R}$ & $\mathrm{F}$ \\
\hline & Great kiskadee (2) & Pitangus sulphuratus & $\mathrm{S}^{* *}$ & $\mathrm{~F}$ \\
\hline & Great kiskadee (3) & Pitangus sulphuratus & $\mathrm{R}$ & $\mathrm{F}$ \\
\hline & Great kiskadee (4) & Pitangus sulphuratus & $S$ & $\mathrm{~F}$ \\
\hline & Great kiskadee (5) & Pitangus sulphuratus & $\mathrm{R}$ & $\mathrm{F}$ \\
\hline & Great kiskadee (6) & Pitangus sulphuratus & $\mathrm{R}$ & $\mathrm{F}$ \\
\hline & Great kiskadee (7) & Pitangus sulphuratus & $\mathrm{R}$ & $\mathrm{N}$ \\
\hline & Great kiskadee (8) & Pitangus sulphuratus & $\mathrm{R}$ & $\mathrm{F}$ \\
\hline & Great kiskadee (9) & Pitangus sulphuratus & $\mathrm{R}$ & $\mathrm{F}$ \\
\hline & Great kiskadee (10) & Pitangus sulphuratus & $\mathrm{R}$ & $\mathrm{F}$ \\
\hline & Monk parakeet & Myiopsitta monachus & $\mathrm{R}$ & $\mathrm{F}$ \\
\hline & Rusty-collared seedeater & Sporophila collaris & $\mathrm{R}$ & $\mathrm{N}$ \\
\hline & American barn owl & Tyto furcata & $\mathrm{R}$ & $\mathrm{N}$ \\
\hline & Great horned owl & Bubo virginianus & $\mathrm{R}$ & $\mathrm{F}$ \\
\hline & Striped owl & Asio clamator & $\mathrm{R}$ & $\mathrm{F}$ \\
\hline & Kelp gull & Larus dominicanus & $\mathrm{R}$ & $\mathrm{F}$ \\
\hline & Short-tailed hawk & Buteo brachyurus & $\mathrm{R}$ & $\mathrm{F}$ \\
\hline & Speckled teal & Anas flavirostris & $\mathrm{R}$ & $\mathrm{F}$ \\
\hline
\end{tabular}




\begin{tabular}{|c|c|c|c|c|}
\hline & white-faced whistling duck (1) & Dendrocygna viduata & $\mathrm{R}$ & $\mathrm{F}$ \\
\hline & white-faced whistling duck (2) & Dendrocygna viduata & $\mathrm{R}$ & $\mathrm{F}$ \\
\hline & Campo flicker & Colaptes campestris & $\mathrm{R}$ & $\mathrm{F}$ \\
\hline & Eared dove (1) & Zenaida auriculata & $\mathrm{R}$ & $\mathrm{F}$ \\
\hline & Eared dove (2) & Zenaida auriculata & $\mathrm{R}$ & $\mathrm{F}$ \\
\hline & Eared dove (3) & Zenaida auriculata & $\mathrm{S}$ & $\mathrm{N}$ \\
\hline & Eared dove (4) & Zenaida auriculata & $\mathrm{R}$ & $\mathrm{N}$ \\
\hline & Southern lapwing & Vanellus chilensis & $\mathrm{R}$ & $\mathrm{F}$ \\
\hline & Rufous-bellied thrush & Turdus rufiventris & $\mathrm{R}$ & $\mathrm{F}$ \\
\hline & Blue-and-yellow tanager & Pipraeidea bonariensis & $\mathrm{S}$ & $\mathrm{N}$ \\
\hline & Fork-tailed flycatcher & Tyrannus savana & $\mathrm{R}$ & $\mathrm{F}$ \\
\hline Mammalia & White-eared opossum (1) & Didelphis albiventris & $\mathrm{S}$ & $\mathrm{N}$ \\
\hline & White-eared opossum (2) & Didelphis albiventris & $\mathrm{S}$ & $\mathrm{F}$ \\
\hline & White-eared opossum (3) & Didelphis albiventris & $\mathrm{R}$ & $\mathrm{F}$ \\
\hline & White-eared opossum (4) & Didelphis albiventris & $\mathrm{S}$ & $\mathrm{F}$ \\
\hline & White-eared opossum (5) & Didelphis albiventris & $\mathrm{S}$ & $\mathrm{N}$ \\
\hline & White-eared opossum (6) & Didelphis albiventris & $\mathrm{R}$ & $\mathrm{F}$ \\
\hline & Capuchin monkey & Sapajus apella & $\mathrm{R}$ & $\mathrm{F}$ \\
\hline & Coypu & Myocastor coypus & $\mathrm{R}$ & $\mathrm{N}$ \\
\hline Reptilia & \multicolumn{2}{|c|}{ South American snake-necked turtle Hydromedusa tectifera } & $\mathrm{R}$ & $\mathrm{N}$ \\
\hline
\end{tabular}

$* \mathrm{R}=$ resistant, $* * \mathrm{~S}=$ sensitive, $* * * \mathrm{~N}=$ not former, $* * * * \mathrm{~F}=$ former. Source: Authors.

$Y$. enterocolitica was isolated from five $(5.10 \%)$ of the 98 mammals collected, three $(21.43 \%)$ of the 14 reptiles and two $(0.94 \%)$ of the 212 birds. The animals from which this pathogen was isolated were four White-eared opossums (Didelphis albiventris), one Southern-tamandua (Tamandua tetradactyla), two D'Orbigny's sliders (Trachemys dorbigini), one Hilaire's toadhead turtle (Phrynops hilarii), one Red-crested cardinal (Paroaria coronata), and one Speckled teal (Anas flavirostris).

Salmonella was isolated from a single animal (0.67\%), a bird of the species Myiopsitta monachus. Campylobacter was also isolated from a single bird $(0.67 \%)$, of the species Columbina talpacoti.

\section{Discussion}

\section{Occurrence of the pathogens in wild animals}

Of the wild animals on rehabilitation sampled in this study, $15.7 \%$ carried some of the microorganisms surveyed. Hence, these animals offer a risk of spreading this pathogen into the environment, in addition to being potential sources of contamination for humans and other animals during their admission time in rehabilitation. Furthermore, some of the animals 
that are admitted in the rehabilitation centers are later released, returning to the natural environment. If they still bear pathogens in their intestines, these microorganisms can spread out into the wild after their release. Nunes et al. (2010) states that wild animals originated from captures and/or trafficking, which was the case of some animals sampled in this study, are potential transmitters of zoonosis if they host pathogens, even if they are healthy. Given this context, this kind of monitoring is of great elevance.

\section{S. aureus}

The occurrence of S. aureus was the most frequent. It was found in $12.3 \%$ of the fecal samples of wild animals of different classes, demonstrating that this microorganism is widely disseminated in the nature and adapts to different species of animals. The high percentage of isolation of $S$. aureus can be attributed to the characteristics of this pathogen, which is frequently found in the airways and gastrointestinal tract of animals and humans (Castro-Silva et al., 2011; Falcão et al., 2006), which are important routes for elimination of the pathogen.

\section{MRSA}

This is the first report of isolation of MRSA from feces of several species of wild animals of the Brazilian fauna. The presence of these animals carrying MRSA wildlife rehabilitation centers highlights the importance of hygienic-sanitary care by the handlers. Some groups of individuals who work closely to the animals, such as veterinarians, have high rates of MRSA colonization (Weese, 2010). Animals have been shown to be a source of human MRSA infection in some circumstances (Weese, 2010). The first methicillin-resistant strains were isolated from humans and farm animals (Morgan, 2008). Different MRSA can be distinguished based on epidemiological groups. Among other groups associated to humans, there is a group associated to hospital-acquired infections (Hospital-associated-MRSA - HA-MRSA) known for decades. Another MRSA, associated to livestock (Livestock-associated-MRSA - LA-MRSA) has emerged in recent years. In addition to being isolated from animals, it can also be isolated from humans (Catry et al., 2010). Porrero et al. (2013) suggested that the contamination of wild animals probably originated from livestock and/or humans. They are also the possible source of the contamination in the region of the present study.

\section{Y. enterocolitica}

It was not the first time that $Y$. enterocolitica was isolated in mammals, birds and reptiles in this rehabilitation center. Silveira et al. (2018), in 2014 and 2015, isolated Y. enterocolitica from feces of wild animals housed in the same center. These authors reported that out of 73 animals sampled, four (5.48\%) hosted this pathogen. However, studies on the role of wild animals as carriers and disseminators of this pathogen are scarce.

\section{Campylobacter}

We considered the occurrence of this pathogen in wild animals as rare, after a single isolation from the 324 samples analyzed. This is the bacterium that causes the greatest number of diarrhea cases in developed and developing countries, and is frequently reported by health agencies in the United States (Centers for Disease Control and Prevention, 2017), but data addressing its occurrence in wild animals are scarce.

\section{Salmonella}

The Salmonella isolate obtained from a single sample was possibly a strain with high specificity to the host. It is 
already known that certain Salmonella variants seem to be specialized in hosts from certain species, as already described in pigeons (Smyser et al., 1972), ducks (Rabsch et al., 2002) and hedgehogs (Handeland et al., 2002). These variants present lower potential of infection and colonization of hosts from other species (Söderlund et al., 2019), which would corroborate to the rare occurrence observed.

\section{Pathogens in wild birds}

\section{Carrier birds}

It has been shown that $S$. aureus can be hosted by 17 different bird species (Table), and more frequently in some, such as Pitangus sulphuratus, Zenaida auriculata, Progne tapera and Dendrocygna viduata, a species already identified as a reservoir in a zoo in Germany (Febler et al. 2018). Febler et al. (2018) indicated as a reservoirs of S. aureus five other bird species: Spatula discors, Cygnus atratus, Sibirionetta formosa, Haliaeetus albicilla and Milvus milvus. Monecke et al. (2016) identified nine species as carriers: Cygnus olor, Aquila chrysaetos, Haliaeetus albicilla, Strix aluco, Perdix perdix, Picus viridis, Pica pica, Corvus frigilegus and Parus major, all captured in Germany, Austria and Sweden. Our results, when compared to the European reports, demonstrate that the wide distribution of S. aureus in wild birds observed in those regions also occur in Southern Brazil.

Although this is the first report of Salmonella isolated from M. monachus, an abundant psittacide of the region of the study (Timm and Timm, 2016), this pathogen has already been isolated from other species of wild birds in Brazil. Dias (2015), after collecting fecal samples from 214 wild birds of various species captured in the surroundings of poultry facilities in the extreme south of Brazil, observed the presence of Salmonella in Sicalis flaveola. The presence of Salmonella in wild birds was also identified in Calidris fuscicollis from the coastal region of the Rio Grande do Sul state (Gomes et al., 2015).

Campylobacter was isolated from a C. talpacoti chick. Studies in the same region indicate the occurrence of this microorganism in other passerines, C. ruficapillus, S. flaveola and Zonotrichia capensis (Rufous-collared sparrow) (Dias et al., 2014; Dias, 2015), all of which are free-living species, indicating that this group of birds is a possible reservoir. Like these species of passerines, C. talpacoti is a granivorous species (Hart, 2020) that tends to be present in environments next to human activities, seeking to benefit from the availability of food (Timm and Timm, 2016).

$Y$. enterocolitica was isolated from P. coronata and A. flavirostris. This pathogen had already been isolated from Vanellus chilensis and Turdus rufiventris by Silveira et al. (2018) in the same center, although in a sectional collection. Our results, when compared to the literature, demonstrate that wild birds in this rehabilitation center frequently host $Y$. enterocolitica. A specific serotype of $Y$. enterocolitica has been identified by Hicks et al. (2020) in routine cultures of a variety of species of wild animals housed in a zoo and aquarium in the United States. Animals of 12 species hosted Y. enterocolitica, but the birds were asymptomatic. The authors concluded that it was a single introduction of the pathogen in the zoo and subsequent dissemination, as the same strain was isolated from all animals. This situation is different from that found in the center of the present study, where eventually carrier birds are detected, including those that had just been admitted to the center. In contrast, Castro-Silva et al. (2011) and Dias et al. (2019) assessed fecal samples from 92 and 189 wild birds in Brazil, respectively, and could not isolate $Y$. enterocolitica.

\section{Dissemination of pathogens by birds}

The bird species identified in the present study as hosts of pathogens of one health concern belong to different orders and families and have different living habits (Billerman et al., 2020), which can influence their potential to disseminate microorganisms. Z. auriculata, P. tapera and M. monachus are birds that usually live in flocks, being able to transmit 
pathogens to other birds in the flock and to the environment, in the areas that they fly over and take shelter. C. talpacoti, $P$. sulphuratus, V. chilensis, Colaptes campestres, T. rufiventris, Sporophila collaris, Tyrannus savana, Anas flavirostris, D. viduata, Larus dominicanus and Pipraeidea bonariensis are found in rural areas in search for food and shelter, and therefore, they may interact with domestic animals and people in these environments. On the other hand, Tyto furcata, Bubo virginianus, Asio clamator e Buteo brachyurus are more solitary birds, but there is still contact between animals, mainly through interactions with individuals of the same species. Emphasis should be given to migratory species, such as Progne tapera e Tyrannus savana, which have a much greater geographic dissemination potential, since they fly for longer distances.

\section{Pathogens in wild mammals}

\section{Carrier mammals}

The high occurrence of pathogens in mammal species under rehabilitation is considered an issue for human health (Wardyn et al., 2012). Six isolates of S. aureus and four isolates of $Y$. enterocolitica from D. albiventris were obtained, stressing the importance of this marsupial as a pathogen carrier. For the first time, Myocastor coypus and Sapajus apella were found carrying $S$. aureus and T. tetradactyla carrying $Y$. enterocolitica.

Four out of the eight (50\%) isolates of $S$. aureus obtained from mammalian samples were sensitive to methicillin, that is, $28.6 \%$ (4/14) of the sampled mammals carried MRSA. In contrast, Espinosa-Gongora et al. (2012), in Denmark, observed that $100 \%$ of the $S$. aureus isolates obtained from the mammals they analyzed were methicillin sensitive, however the species they studied were not the same ones that we analyzed in this study. Porrero et al. (2013) analyzed samples from 1,342 freeliving wild animals from different areas in Spain. The mammal species they sampled were Cervus elaphus, Capra pyrenaica and Sus scrofa. These authors found a low prevalence of MRSA: 13 isolates, obtained from 12 animals (0.89\%). However, they stress that free-living wild animals can act as MRSA reservoirs and represent a potential risk for human health. Hence, the prevalence of $9.88 \%$ of MRSA found in animals collected in the rehabilitation center should be considered high.

Although the isolation of Salmonella from samples obtained from mammals and reptiles has not occurred in the rehabilitation center, this pathogen has already been isolated from the gastrointestinal tract of captive wild mammals in Brazil (Gomes et al., 2011). Sá and Solari (2001) isolated Salmonella in 39.1\% of the Brazilian and imported reptiles they studied. Both studies obtained isolates from animals of species different from the aforementioned in the present study and were carried out in other Brazilian regions, which may have contributed to the different results found.

\section{Dissemination by mammals}

D. albiventris was the most frequent mammal in the center and also the main carrier of $S$. aureus and $Y$. enterocolitica. Silveira et al. (2018) considered D. albiventris to be an important reservoir and possible source of dissemination of $Y$. enterocolitica, due to its vast eating habits and frequent contact with farm animals.

Despite of the prohibition of hunting, apprehensions of M. coypus from illegal hunting eventually occur in the region (Civil Police of the State of Rio Grande do Sul, 2019), denoting that the occurrence of this activity could facilitate the contact or consumption of the meat from contaminated animals. As for the presence of the pathogen in the primate species S. apella, there is a greater risk of direct contamination of humans during the rehabilitation period, due to the close proximity that this species usually requires for stablishing sociable relationships with handlers. As for the animals that hosted Y. enterocolitica, the mammal $T$. tetradactyla is found predominantly in the rural area of the region and eventually at roadsides, with less likelihood of spreading diseases to humans when compared to other mammals bearing pathogens. 


\section{Pathogens in wild reptiles}

\section{Carrier reptiles}

In our study, MRSA was isolated from Hydromedusa tectifera. The presence of S. aureus in animals in a zoo was studied by Espinosa-Gongora et al. (2012) in Copenhagen, Denmark. These authors did not isolate S. aureus from any of the 21 reptiles analyzed, considering them improbable hosts, which was contested by the results of our study. The differences in results seen between the two studies may be due to the distinct regions and species sampled, and also to the fact that the animals sampled in the present study were from a rehabilitation center and had a previous life outside of this center (free or in captivity) until the week they were sent to the center and sampled. Y. enterocolitca was isolated from the species T. dorbigini after the collection of 14 reptiles. This low occurrence suggests that reptiles act as occasional carriers of $Y$. enterocolitica. The samples were collected by the time the animals were admitted to the centers, demonstrating that the contamination occurred prior to rehabilitation. However, this pathogen has already been isolated in the same rehabilitation center from a single individual among 23 sampled reptiles. The animal of the species Pantherophis guttatus had been under care from the hatching of the egg (Silveira et al., 2018); therefore, the contamination of this snake certainly occurred within the center. The study by Silveira et al. (2018) was a one-off survey, with no monitoring of admittance of new animals in the center. Although other sources of contamination cannot be ruled out, the present study confirms the entry of $Y$. enterocolitica to the center via carrier animals, indicating that monitoring of animals upon arrival is an important measure to control the spread of microorganisms among the animals housed.

\section{Dissemination by reptiles}

The reptile species $T$. dorbigini and $P$. hilarii are commonly found in lakes, both in rural areas and in recreational squares in urban areas. Therefore, as carriers of $Y$. enterocolitica and MRSA they can spread these pathogens to other wild animals, domestic animals and even to humans, indirectly, in these environments.

\section{Transmission possibilities}

Sample collection was carried out when the animals were admitted or had been recently admitted to the rehabilitation center, which means that contamination by pathogens probably occurred prior to their contact with the environment, other animals or humans inside the center. Considering that many of the wild animals that were admitted to the rehabilitation center had previous contact with domestic animals and humans, this option should be considered as a possible source of contamination. However, environmental contamination should also be considered (de Sá \& Ferreira, 2007), as some wild animals of free life arrive at the center without having had previous contact with humans and domestic animals.

According to Steele et al. (2005), the contamination of animals and humans by pathogens in rehabilitation centers can be avoided, since these microorganisms are disseminated, in most instances, via the fecal-oral route. This spread can be reduced with proper hygiene, handling and disinfection of facilities and equipment. Thus, the results of this study are an important tool to define strategies for controlling the transmission of pathogens by wild animals.

\section{Isolates capable of forming biofilm}

The $72.5 \%$ of the isolates of $S$. aureus being capable to form biofilm is highly significant, as it can generate difficulties in the disinfection of facilities and cages. The ability to form biofilms promotes the persistence of the pathogen in the environment (Archer et al., 2011). When it is present in wildlife rehabilitation centers, the ability to form biofilms increases the risk of contamination infection of animals and humans. In this condition, the bacteria are less susceptible to the action of 
antibacterials and can reach a sufficient number to represent a potential infectious dose (Davies, 2003).

Of the 29 biofilm-forming isolates, 25 (86.2\%) were MRSA, which demonstrates that strains of S. aureus with both biofilm formation capacity and antimicrobial resistance can be isolated from wild animals undergoing rehabilitation. This double capacity, biofilm formation and antibiotic resistance of S. aureus isolates, was also observed by Chen et al. (2020). After a study characterizing isolates obtained from veterinary hospitals in Guangzhou, China, from samples of domestic animals and animals from other sources, these authors observed, as in our study, that the occurrence of MRSA strains and strains able to form biofilms in animals under treatment/rehabilitation is frequent.

\section{Conclusion}

A wide diversity of animal species in rehabilitation centers, including birds, mammals and reptiles, can carry and eliminate S. aureus (MRSA and biofilm-forming strains) in the feces. D. albivens, T. dorbigini, P. hilarii, T. tetradactyla, P. coronata and A. flavirostris can carry Y. enterocolitica, C. talpacoti can carry Campylobacter sp. and M. monachus, Salmonella enterica.

The presence of these pathogens of one health concern in the gastrointestinal tract of wild animals admitted to wildlife rehabilitation centers shows the importance of microbiological monitoring of animals at the time they are admitted and reinforces the need for specific hygienic-sanitary care, to avoid dissemination through the environment and transmission to humans and other animals.

Future directions in controlling the presented bacteria, point to the need for biofilm control studies (such as which sanitizers are effective in controlling pathogens in places that house animals), as well as which hygienic-sanitary measures would be effective in reducing the risk of transmission to both other animals, and human beings. On the other hand, phylogenetic studies of pathogens housed by wild animals are necessary to better understand how their dissemination occur. Only by understanding this, will it be possible to efficiently control the spreading of pathogens by - and for - wild animals.

\section{Acknowledgments}

This study was financed in part by the Coordination for the Improvement of Higher Education Personnel (CAPES) Financial Code 001.

\section{References}

Andrews, W. H., Andrew, J. \& Hammack, T. (2014). Salmonella. U.S. Food and Drug Administration, Bacteriological analytical manual (BAM), Chap. 5, 2014. http://www.fda.gov/Food/FoodScienceResearch/LaboratoryMethods/ucm070149.htm

Archer, N. K., Mazaitis, M. J., Costerton, J. W., Leid, J. G., Powers, M. E. \& Shirtliff, M. E. (2011). Staphylococcus aureus biofilms: Properties, regulation, and roles in human disease. Virulence, 2(5), 445-459.

Billerman, S. M., Keeney, B. K., Rodewald, P. G. \& Schulenberg, T. S. (2020). Birds of the World. Cornell Laboratory of Ornithology, Ithaca, NY, USA. Retrieved from https://birdsoftheworld.org/bow/home

Castro-Silva, M. A., Manoel, F. C., Krueger, J., Barreiros, M. A. B., \& Branco, J. O. (2011). Identificação de bactérias potencialmente patogênicas a humanos presentes em Sula leucogaster (Suliformes: Sulidae), no litoral de Santa Catarina, Brasil. Revista Brasileira de Ornitologia, 19(4), $520-524$.

Catry, B., Van Duijkeren, E., Pomba, M. C., Greko, C., Moreno, M. A., Pyörälä, S., Ruz Auskas, M., Sanders, P., Threlfall, E. J., Ungemach, F., Torneke, K., munoz-madero, C., \& Törneke, K. (2010). Reflection paper on MRSA in food-producing and companion animals: epidemiology and control options for human and animal health. Epidemiology and Infection, 138(5), 626-644.

Centers for Desease Control and Prevention - CDC. 2017. Morbidity and Mortality Weekly Report - MMWR. Notifiable Diseases and Mortality Tables. https://www.cdc.gov/mmwr/volumes/66/wr/mm6650md.htm?s_cid=mm6650md_w

Chambers, H. F. (2001). The changing epidemiology of Staphylococcus aureus? Emerging Infectious Diseases, 7(2), 178. 
Chen, L., Tang, Z. Y., Cui, S. Y., Ma, Z. B., Deng, H., Kong, W. L., Yang, L. W., Lin, C., Xiong, W. G., \& Zeng, Z. L. (2020). Biofilm Production Ability, Virulence and Antimicrobial Resistance Genes in Staphylococcus aureus from Various Veterinary Hospitals. Pathogens, 9(4), 264.

CLSI. (2015). Performance Standards for Antimicrobial Susceptibility Testing. Twenty Fourth Informational Supplement. CLSI document M100-S24. Wayne: Clinical and Laboratory Standards Institute.

Costa, H. C., \& Bérnils, R. S. (2015). Répteis brasileiros: lista de espécies 2015. Herpetologia Brasileira, 4(3), 75-93.

De Sá, M. I. \& Ferreira, C. (2007). Importância das zoonoses na segurança alimentar. http://www.infoqualidade.net/SEQUALI/PDF-SEQUALI-02/n02-1417.pdf

Dias, P. A., Wilsmann, D. E., Heinen, J. G., Corsini, D. F., Calabuig, C., \& Timm, C. D. (2014). Primeiro relato de Salmonella enterica e Campylobacter spp. isolados de Garibaldi (Chrysomus ruficapillus) e Canário-da-terra (Sicalis flaveola) silvestres. Revista do Instituto Adolfo Lutz, 73, 368-71.

Dias, P. A. (2015). Campylobacter spp., Salmonella enterica e Yersinia enterocolitica em aves silvestres e frangos de corte. 55f. Pelotas - RS. Tese (Doutorado em Veterinária) - Programa de Pós-graduação em Veterinária, Universidade Federal de Pelotas.

Dias, P. A., Moraes, T. P., Wilsmann, D. E., Ferrasso, M. M., Marinheiro, M. F., Heinen, J. G., Calabuig, C. I. P. \& Timm, C. D. (2019). Ocorrência de Campylobacter e Enterobacteriaceae em aves silvestres e frangos de corte. Arquivo Brasileiro de Medicina Vetetrinária e Zootecnia, 71(1), $225-231$.

Davies, D. (2003). Understanding biofilm resistance to antibacterial agents. Nature Reviews Drug Discovery, 2(2), 114-122.

Donlan, R. M. \& Costerton, J. M. (2002). Biofilms: survival mechanisms of clinically relevant microorganisms. Clinical Microbiology Reviews, 15(2), 167193.

Espinosa-Gongora, C., Chrobak, D., Moodley, A., Bertelsen, M. F. \& Guardabassi, L. (2012). Occurrence and distribution of Staphylococcus aureus lineages among zoo animals. Veterinary Microbiology, 158(1-2), 228-231.

Falcão, J. P., Falcão, D. P., Pitondo-Silva, A., Malaspina, A. C. \& Brocchi, M. (2006). Molecular typing and virulence markers of Yersinia enterocolitica strains from human, animal and food origins isolated between 1968 and 2000 in Brazil. Journal of Medical Microbiology, 55(11), 1539-1548.

Febler, A. T., Thomas, P., Mühldorfer, K., Grobbel, M., Brombach, J., Eichhorn, I., Monecke, S., Ehricht, R. \& Schwarz, S. (2018). Phenotypic and genotypic characteristics of Staphylococcus aureus isolates from zoo and wild animals. Veterinary Microbiology, 218, 98-103.

Felten, A., Grandry, B., Lagrange, P. H. \& Casin, I. (2002). Evaluation of three techniques for detection of low-level methicillin-resistant Staphylococcus aureus (MRSA): a disk diffusion method with cefoxitin and moxalactam, the Vitek 2 system, and the MRSA-screen latex agglutination test. Journal of Clinical Microbiology, 40(8), 2766-2771.

Freeman, D. J., Falkiner, F. R. \& Keane, C. T. (1989). New method for detecting slime production by coagulase negative staphy lococci. Journal of Clinical Pathology, 42(8), 872-874.

Friedriczewski, A. B., Gandra, E. Á., Cereser, N. D., Moreira, L. M. \& Timm, C. D. (2018). Biofilm Formation by Coagulase-Positive Staphylococcus aureus Isolated from Mozzarella Cheese Elaborated with Buffalo Milk and its Effect on Sensitivity to Sanitizers. Acta Scientiae Veterinariae, 46(1), 1-6.

Gomes, C. M. B., Batista K. S., Oliveira, S. A. \& Bezerra L. M. (2011). Determinação de enterobactérias de mamíferos silvestres em criadouro conservacionista. Revista de Biologia e Ciências da Terra, 11(2), 74-80.

Gomes, S., De Macedo, M. R. P., Pesenti, T., Pereira, D. I. B., Cirne, M. P. \& Müller, G. (2015). Isolamento de Salmonella enterica subsp. diarizonae em Calidris fuscicollis (Aves: Scolopacidade) no Rio Grande do Sul, Brasil. Ornithologia, 8(1), 43-45.

Handeland, K., Refsum, T., Johansen, B. S., Holstad, G., Knutsen, G., Solberg, I., Schulze, J. \& Kapperud, G. (2002). Prevalence of Salmonella Typhimurium infection in Norwegian hedgehog populations associated with two human disease outbreaks. Epidemiology and Infection, 128(3), 523-7.

Hart, J. A. (2020). Ruddy Ground Dove (Columbina talpacoti), version 1.0. In Birds of the World. T. S. Schulenberg, Editor. Ithaca: Cornell Lab of Ornithology.

Hicks, C. L., Napier, J. E., Armstrong, D. L., Gladney, L. M., Tarr, C. L., Freeman, M. M. \& Iwen, P. C. (2020). Clonal spread of Yersinia enterocolitica 1B/O: 8 in multiple zoo species. Journal of Zoo and Wildlife Medicine, 51(1), 170-176.

Mariana, N. S., Salman, S. A., Neela, V. \& Zamberi, S. (2009). Evaluation of modified Congo red agar for detection of biofilm produced by clinical isolates of methicillin resistance Staphylococcus aureus. African Journal of Microbiology Research, 3(6), 330-338.

Monecke, S., Gavier-Widén, D., Hotzel, H., Peters, M., Guenther, S., Lazaris, A., Loncaric, I., Müller, E., \& Reissig, A. (2016). Diversity of Staphylococcus aureus isolates in European wildlife. Plos One, 11(12), e0168433.

Morgan, M. (2008). Methicillin-resistant Staphylococcus aureus and animals: zoonosis or humanosis? Journal of Antimicrobial Chemotherapy, 62(6), 11811187 .

Nunes, H., Rocha, F. L. \& Cordeiro-Estrela, P. (2017). Bats in urban areas of Brazil: roosts, food resources and parasites in disturbed environments. Urban Ecosystems, 20(4), 953-969.

Oliveira, S. D., Rodenbusch, C. R., Cé, M. C., Rocha, S. L. S. \& Canal, C. W. (2003). Evaluation of selective and nonselective enrichment PCR procedures for Salmonella detection. Letters in Applied Microbiology, 36(4), 217-221. 
Paglia, A. P., Fonseca, G. A. B., Rylands, A. B., Herrmann, G., Aguiar, L. M. S., Chiarello, A. G., Leite, Y. L. R., Costa, L. P., Siciliano, S., Kierulff, M. C. M., Mendes, S. L., Tavares, V. C., Mittermeier, R. A. \& Patton, J. L. (2012). Lista Anotada dos Mamíferos do Brasil. Occasional Papers in Conservation Biology $\mathrm{n}^{\circ} 6.2^{\circ} \mathrm{ed}$. Conservation International: Arlington, 76p.

Pereira, A. S., Shitsuka, D. M., Parreira, F. J., \& Shitsuka, R. (2018). Metodologia da pesquisa científica. Ed. UAB/NTE/UFSM. https://repositorio. ufsm. br/bitstream/handle/1/15824/Lic_Computacao_Metodologia-Pesquisa-Cientifica. pdf.

Piacentini, V. Q., Aleixo, A., Agne, C. E., Maurício, G. N., Pacheco, J. F., Bravo, G. A., Brito, G. R. R., Naka, L. N., Olmos, F., Posso, S., Silveira, L. F., Betini, G. S., Carrano, E., Franz, I., Lees, A. C., Lima, L. M., Pioli, D., Schunck, F., Amaral, F. R., Bencke, G. A., Cohn-Haft, M., Figueiredo, L. F., Straube, F. C. \& Cesari, E. (2015). Lista comentada das aves do Brasil pelo Comitê Brasileiro de Registros Ornitológicos. Revista Brasileira de Ornitologia, 23(2), 91298.

Polícia Civil do Estado do Rio Grande do Sul. 2019. Operação Bad Hunters investiga crimes de caça ilegal de animais silvestres no norte gaúcho. https://www.pc.rs.gov.br/operacao-bad-hunters-investiga-crimes-de-caca-ilegal-de-animais-silvestres-no-norte-gaucho

Porrero, M. C., Mentaberre, G., Sánchez, S., Fernández-Llario, P., Gómez-Barrero, S. Navarro-Gonzalez, N., Serrano, E., Casas-Díaz, E., Marco, I., Fernández-Garayzabal, J. F., Mateos, A., Vidal, D., Lavín, S., \& Domínguez, L. (2013). Methicillin resistant Staphylococcus aureus (MRSA) carriage in different free-living wild animal species in Spain. The Veterinary Journal, 198(1), 127-130.

Rabsch, W., Andrews, H. L., Kingsley, R. A., Prager, R., Tschäpe, H., Adams, L. G. \& Bäumler, A. J. (2002). Salmonella enterica serotype Typhimurium and its host-adapted variants. Infection and Immunity, 70(5), 2249- 55.

Rubini, S., Ravaioli, C., Previato, S., D’Incau, M., Tassinari, M., Guidi, E. \& Bergamini, M. (2016). Prevalence of Salmonella strains in wild animals from a highly populated area of north-eastern Italy. Annali dell'Istituto Superiore di Sanità, 52(2), 277-280.

Sá, I. V. A. D., \& Solari, C. A. (2001). Salmonella in Brazilian and imported pet reptiles. Brazilian Journal of Microbiology, 32(4), $293-297$.

Sambrook, J. \& Russel, D. W. (2001). Molecular Cloning: A Laboratory Manual. (3a ed.), Cold Spring Harbor Laboratory Press, 999 p.

Sasaki, T., Tsubakishita, S., Tanaka, Y., Sakusabe, A., Ohtsuka, M., Hirotaki, S., Kawakami, T., Fukata, T. \& Hiramatsu, K. (2010). Multiplex-PCR method for species indentification of coagulase-positive Staphylococci. Journal of Clinical Microbiology, 48(3), 765-769.

Silva, H. R., Rocha, Á. S. C., Rocha, M. V. S., Veras, D. M., de Sousa, O. M. C., da Costa Sousa, G., Almeida, D. F., Oliveira, A. L. P., Bezerra, G. S. S., Ribeiro, D. A. S., Pereira N. M., Alves, A. K. R., Silva, B. B. L., Nogueira, F. D., Rodrigues, F. L. G. \& Pessoa, G. T. (2020). Reflexo do desequilíbrio ambiental na saúde: bactérias multirresistentes em ambiente hospitalar. Research, Society and Development, 9(8), e220985604-e220985604.

Silveira, D. R., Milan, C., Ferrasso, M. M., Dias, P. A., Moraes, T. P., Bandarra, P. M., Minello, L. F. \& Timm, C. D. (2018). Campylobacter jejuni, Campylobacter coli, Salmonella spp. e Yersinia enterocolitica isoladas de animais silvestres em um centro de reabilitação. Pesquisa Veterinária Brasileira, 38(9), 1838-1843.

Skov, R., Smyth, R., Clausen, M., Larsen, A. R., Frimodt-Moller, N., Olsson-Lijequist, B. \& Kahlmeter, G. (2003). Evaluation of a cefoxitin 30 microg disc on Iso-Sensitest agar for detection of methicillin resistant Staphylococcus aureus. Journal of Antimicrobial Chemotherapy, 52(2), 204-207.

Smyser, C. F. \& Snoeyenbos, G. H. (1972). A pigeon host-adapted type of Salmonella typhimurium var. Copenhagen. Avian diseases, 16(2), $270-277$.

Söderlund, R., Jernberg, C., Trönnberg, L., Pääjärvi, A., Ågren, E. \& Lahti, E. (2019). Linked seasonal outbreaks of Salmonella Typhimurium among passerine birds, domestic cats and humans, Sweden, 2009 to 2016. Eurosurveillance, 24(34), 1-10.

Steele, C. M., Brown, R. N. \& Botzler, R. G. (2005). Prevalence of zoonotic bacteria among seabirds in rehabilitation centers along the Pacific Coast of California and Washington, USA. Journal of Wildlife Diseases, 41(4), 735-744.

Timm, C. D., Dias, P. A., Conceição, R. C. S., Lima, H. G., Silveira, D. R. (2016). Manual de técnicas microbiológicas em leite e derivados. do autor, 88 p.

Timm, C. D. \& Timm, V. F. (2016). Aves do extremo sul do Brasil: guia de identificação. Pelotas: Useb. 334 p.

Tompkins, D. M., Carver, S., Jones, M. E., Krkošek, M. \& Skerratt, L. F. (2015). Emerging infectious diseases of wildlife: a critical perspective. Trends in Parasitology, 31(4), 149-159.

Wannet, J. B. W., Reessink, M. \& Brunings, H. A. (2001). Detection of pathogenic Yersinia enterocolitica by a rapid and sensitive Duplex PCR assay. Journal of Clinical Microbiology, 39(12), 4483-4486.

Wardyn, S. E., Kauffman, L. K. \& Smith, T. C. (2012). Methicillin-resistant Staphylococcus aureus in central Iowa wildlife. Journal of wildlife Diseases, 48(4), 1069-1073.

Weagant, S. D. \& Feng, P. (2017). Yersinia enterocolitica. U.S. Food and Drug Administration, Bacteriological analytical manual (BAM), Chap. 8, 2017. Retrieved from URL https://www.fda.gov/food/foodscienceresearch

Weese, J. S. \& Van Duijkeren, E. (2010). Methicillin-resistant Staphylococcus aureus and Staphylococcus pseudintermedius in veterinary medicine. Veterinary Microbiology, 140(3-4), 418-429.

Yabsley, M. J. (2019). The Role of Wildlife Rehabilitation in Wildlife Disease Research and Surveillance. Medical Management of Wildlife Species: A Guide for Practitioners, 159-165, 2019. 